\title{
The Taiwanese connection-a new peril for rhinos
}

\author{
Esmond Bradley Martin and Chryssee Bradley Martin
}

In 1985 Taiwan responded to widespread concern about its role in the international rhinoceros trade by banning imports and exports of all rhinoceros products. It is disheartening and alarming that, three years later, the trade still thrives and little has been done to enforce the new law. The authors describe the situation in Taiwan, discuss the implications for the world's last rhinoceros populations and recommend what action should be taken.

Today there is probably more rhinoceros horn for sale in Taiwan (the Republic of China) than anywhere else. Moreover, during the last three years the country has become what may well be the world's largest entrepôt for the horn of both African and Asian species of rhino. Even though imports and exports are illegal, the trade thrives, with Taiwanese businessmen purchasing large quantities of horn from South Africa, Malaysia, Hong Kong and Thailand, which they smuggle into Taiwan by air and sea.

Taiwan became a significant importer of rhino horn in the early 1970s when the economy began to boom, and the people had more money to spend. According to Customs statistics, $7281 \mathrm{~kg}$ were imported between 1972 and August 1985. However, considerable additional quantities came into the country unofficially because some traders did not declare their imports to avoid paying taxes. The role of Taiwan in the international trade in rhino horn prompted international conservation organizations, especially the World Wide Fund for Nature (WWF), to encourage Taiwan to ban imports and exports of all rhinoceros products, which the government duly did in August 1985 (Martin and Vigne, 1987).

Four months later, EBM went to Taiwan under the auspices of WWF to discuss the implementation of the new law with Dr Feng-shu Chang, who is a Minister of State without portfolio and 76 the President of the Society for Wildlife and Nature. He also had meetings with two other Ministers, Department Heads and senior officials. All agreed that a high priority should be given to enforcing the law, and ways of curtailing trade in rhino horn and hide were proposed.

During that December 1985 visit, a survey of the main wholesalers and traditional medicine shops in Taipei, Kaohsiung and Tainan revealed hundreds of kilogrammes of rhino horn for sale. In Taipei, the capital city, 76 per cent of the pharmacies investigated offered rhino horn. White rhino Ceratotherium simum horn imported from South Africa was particularly abundant, and not just in small pieces. Many shops had whole horns, and some had extensive stocks. There were 35 white rhino horns in one pharmacy alone.

In 1970 Taiwan's average income per person was only US $\$ 390$ but by 1988 this had increased by more than 15 times to US $\$ 6000$, and the country had become one of the richest in Asia. Foreign currency reserves of over US $\$ 75$ billion are now the third highest total in the world, and from a per capita standpoint are the highest for any industrialized country. The New Taiwanese dollar has gone up 40 per cent in value against the US dollar since early 1986.

One effect of the rapid economic growth is that there is an excessive amount of cash in the economy since the Taiwanese, unlike their more

Oryx Vol 23 No 2, April 1989 
sophisticated trading competitors in Japan and Hong Kong, have generally been reluctant to invest overseas and keep large credit balances in the local banks. Regrettably, the Taiwanese are using some of their money to buy rare fish, birds and even orang-utans as pets. They are also importing elephant ivory (over 80 tonnes were imported in 1987) and they have now begun to invest in rhino horn.

When we returned to Taiwan in July 1988 to ascertain how effectively the 1985 ban on imports and exports of rhino products was being enforced, we were thoroughly dismayed. According to traders, owners of medicine shops and pharmacists, the government had made almost no effort in the intervening three years either to control the trade or to encourage the use of substitutes.

The retail prices for African and Asian rhino horn had risen sharply since the previous visit due to an even greater demand. The horns of Indian rhino Rhinoceros unicomis and Sumatran rhino Dicerorhinus sumatrensis now retail for over US $\$ 40,000 \mathrm{a} \mathrm{kg}$, the highest price in the world (Table 1). The retail price for African horn in
Kaohsiung, the main port and second largest city, had doubled between April and July 1988, from US $\$ 1536$ to US $\$ 3347$ per $\mathrm{kg}$. The cause for the tremendous increase in demand was threefold. Most disturbing is a belief that because the world's rhino populations have fallen from more than 70,000 in 1970 to about 10,500 in 1988 , rhinos will soon disappear from the wild. This has led to the decision to buy rhino horn as an investment. We know of no other country where businessmen are building up stocks of rhino horn for investment purposes, but if they did, this certainly would be catastrophic for the remaining rhinos. The Taiwanese think that if they can obtain large supplies and hold on to them for a while they will produce an excellent financial return.

In Taiwan itself, pharmacy shops are doing a brisk business in rhino horn as many of the $20,000,000$ Taiwanese prefer rhino horn to any other traditional drug for lowering fever, and the average consumer can afford the increased prices. Despite the illegality of imports, 73 per cent of the larger medicine shops in Taipei and nearly 90 per cent of those in Kaohsiung openly

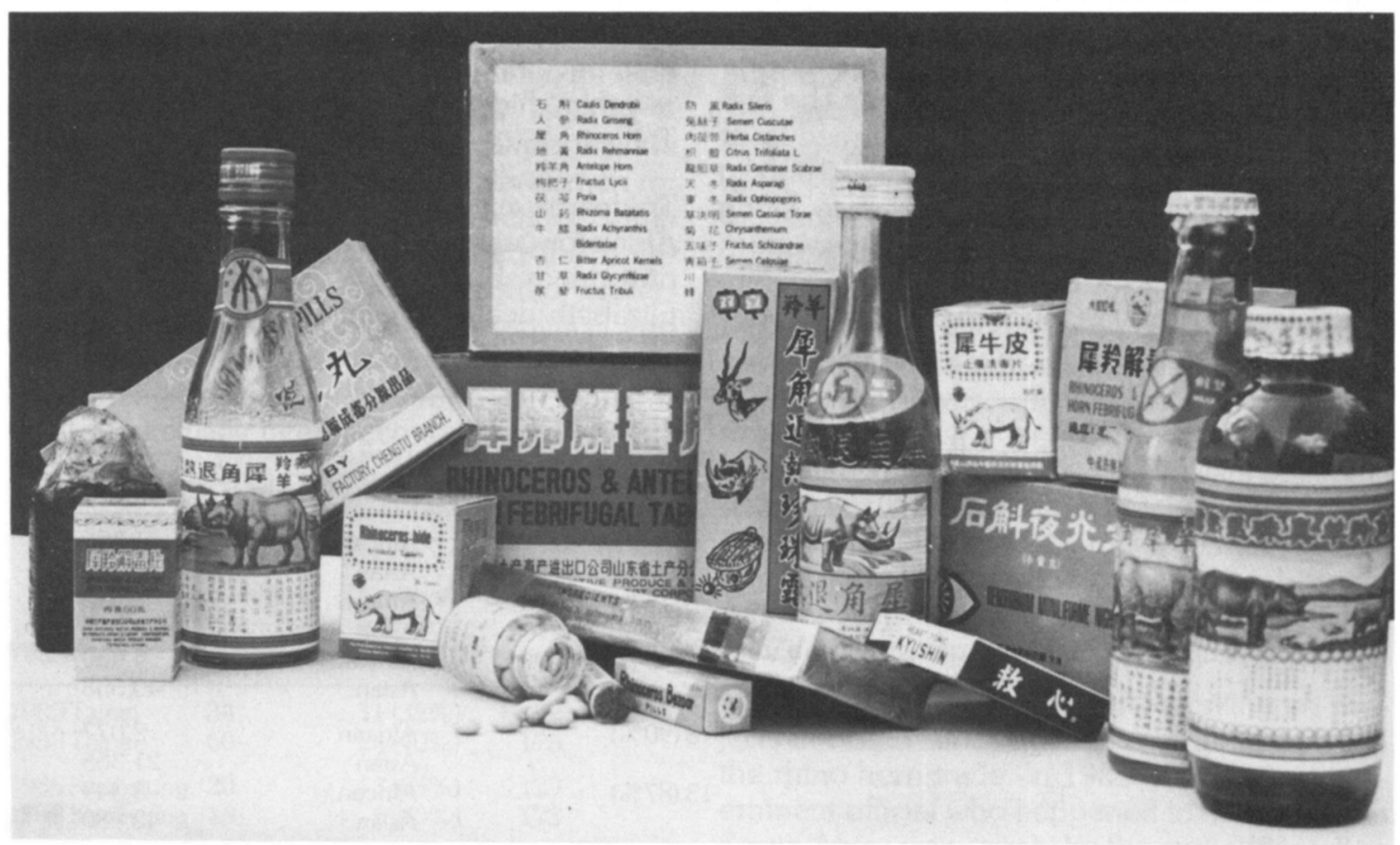

Rhino horn medicines such as these are smuggled from China into Taiwan by boat (Esmond Bradley Martin). 
offer rhino horn for sale. About one-quarter of the shops have Asian rhino horn; Indian and Sumatran species are almost equally available. There is no indication that the Taiwanese are becoming significantly less conservative in their outlook towards traditional herbs and animal products as compared with the more westernized Chinese in Hong Kong and Singapore where the demand for rhino horn has been reduced. Nor do the Taiwanese wish to use in place of rhino horn, water buffalo or saiga antelope horn, which are incomparably cheaper and traditionally acceptable substitutes. As long as rhino hom remains readily available they see no reason not to buy it.

A very large demand for rhino horn in Taiwan since 1986 has come from an exterior source: traders in Hong Kong. Since Macao and Singapore officially banned imports and exports of rhino products in December 1985 and October 1986 respectively and have enforced their new laws reasonably well, Taiwan has taken over their roles in the international trade, emerging as the major entrepôt in eastern Asia. Hong Kong traders buy African rhino horn from Taiwanese businessmen mainly for the Chinese mainland market. The horn is ground into powder for patent medicines; only African, not the more expensive Asian horn, is used for these. The two main wholesalers in Kaohsiung confirmed to us that between early 1987 and mid-1988 $1000 \mathrm{~kg}$ were illegally exported from Taiwan to Hong Kong traders. During July 1988 when we were in Taiwan, there was a massive scramble among businessmen to buy as much rhino horn as poss- ible to supply Hong Kong traders for mainland China's medicine factories. The wholesale price in Taipei consequently rose to US $\$ 2486 \mathrm{a} \mathrm{kg}$.

Some of the rhino horn medicines manufactured in mainland China are smuggled into Taiwan. Both countries have huge fleets of fishing boats plying the waters of the Formosa Strait. The crew on an average Taiwanese fishing boat may barter as much as US $\$ 10,000$-worth of goods including television sets, calculators and electronic equipment on one trip in exchange for Chinese liquors, herbs, teas, live birds and patent medicines from the mainland. Although trade between Taiwan and China is illegal, both governments tolerate it.

The only rhino product apart from horn imported into Taiwan is hide, used as a traditional medicine to cure skin diseases. In July 1988, 40 per cent of the medicine shops in Taipei and Kaohsiung offered it for sale, but its average retail price had not risen very much during the past three years (Table 2). Most of it comes from white rhinos in southern Africa, but there is also some imported from Malaysia, and Hong Kong supplies processed slices, which are often fake, being made instead from water buffalo hide. Businessmen have not shown any interest in investing in raw rhino hide, nor do foreign traders buy it from Taiwan.

Traders have been buying rhino horn from South Africa for years. It is difficult to ascertain the export prices, but there is one example of a Port Elizabeth dealer obtaining $99 \mathrm{~kg}$ of rhino hom

Table 1. Average retail prices for rhinoceros horn in Taiwan

\begin{tabular}{|c|c|c|c|c|}
\hline Year \& place & $\begin{array}{l}\text { Total number of } \\
\text { pharmacies visited }\end{array}$ & $\begin{array}{l}\text { Number } \\
\text { (percentage) } \\
\text { selling horn }\end{array}$ & $\begin{array}{l}\text { Type of } \\
\text { horn }\end{array}$ & $\begin{array}{l}\text { Average price } \\
\text { perkg in US } \$\end{array}$ \\
\hline 1979 Taipei & 9 & $9(100 \%)$ & $\begin{array}{l}\text { African } \\
\text { Asian }\end{array}$ & $\begin{array}{r}1,596 \\
17,090\end{array}$ \\
\hline 1985 Taipei & 34 & $26(76 \%)$ & $\begin{array}{l}\text { African } \\
\text { Asian }\end{array}$ & $\begin{array}{r}1,532 \\
23,929\end{array}$ \\
\hline 1988 Taipei & 60 & $44(73 \%)$ & $\begin{array}{l}\text { African } \\
\text { Asian }\end{array}$ & $\begin{array}{r}4,660 \\
40,558\end{array}$ \\
\hline 1985 Kaohsiung & 20 & $18(90 \%)$ & $\begin{array}{l}\text { African } \\
\text { Asian }\end{array}$ & $\begin{array}{r}2,077 \\
21,365\end{array}$ \\
\hline 1988 Kaohsiung & 15 & $13(87 \%)$ & $\begin{array}{l}\text { African } \\
\text { Asian }\end{array}$ & $\begin{array}{r}3,347 \\
42,880\end{array}$ \\
\hline
\end{tabular}

Source: Authors' surveys. 


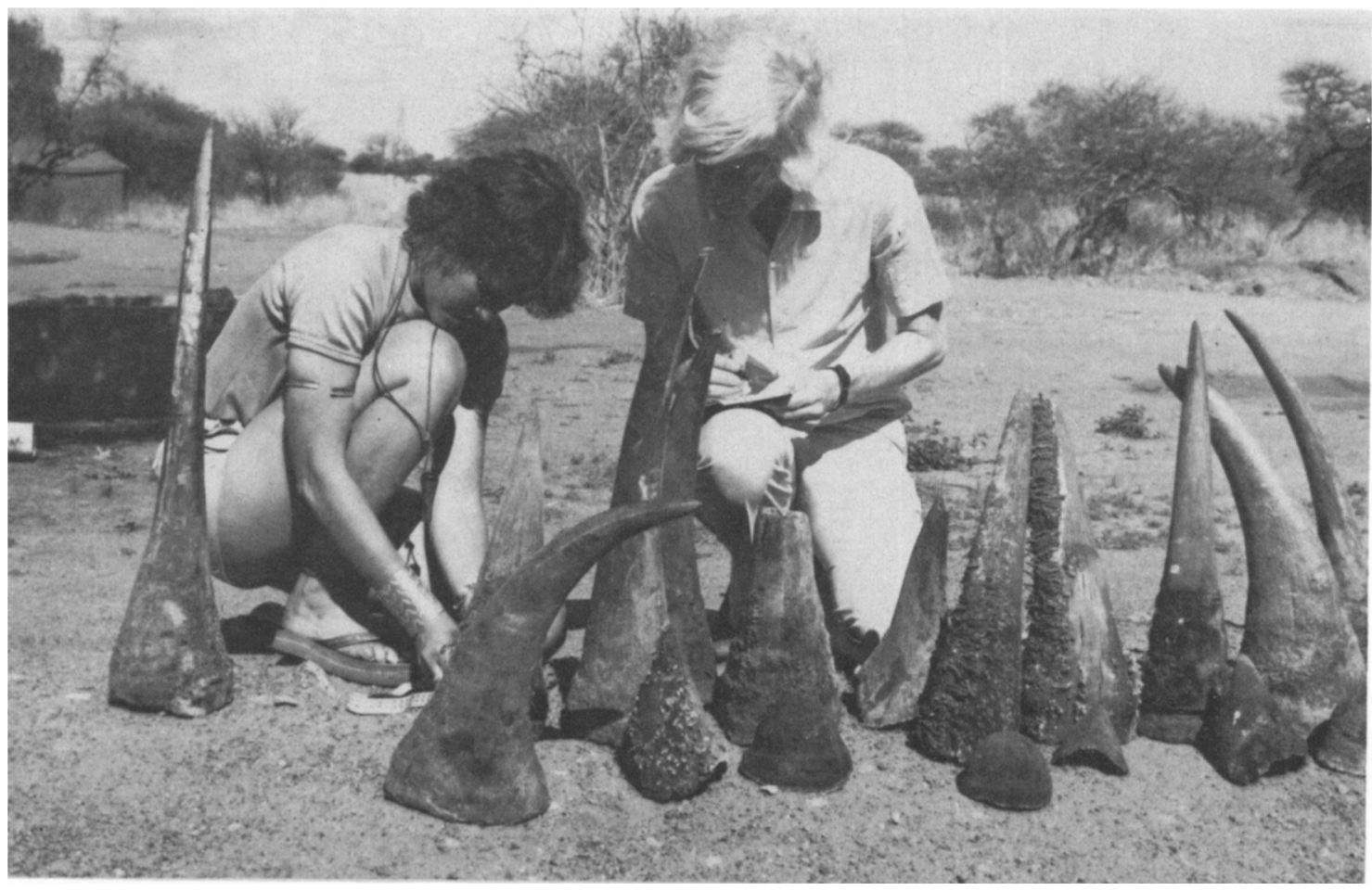

It is possible that some of these white rhino horns from Pilanesberg Game Reserve in Bophuthatswana could have ended up in Taiwan.

from an auction in Windhoek, Namibia, for US\$ 460 per $\mathrm{kg}$ in 1983, which he sold to a businessman in Taipei for US\$750 per kg. He also supplied rhino hide to the businessman for US $\$ 60$ per kg. After mid-1985, neither South Africa nor Taiwan legally permitted this commerce, but the trade has flourished underground. Over the past few years, political and economic relations between the two countries have strengthened. The South African Government has actually been encouraging Taiwanese

Table 2. Average retail prices for rhinoceros hide (mostly from African white rhino species) in Taiwan

\begin{tabular}{llll}
\hline & $\begin{array}{l}\text { Total } \\
\text { number of } \\
\text { pharmacies } \\
\text { visited }\end{array}$ & $\begin{array}{l}\text { Number } \\
\text { (percentage) } \\
\text { selling hide }\end{array}$ & $\begin{array}{l}\text { Average price } \\
\text { perkg in US\$ }\end{array}$ \\
\hline 1985 Taipei & 34 & $11(32 \%)$ & 152 \\
1988 Taipei & 60 & $24(40 \%)$ & 175 \\
1985 Kaohsiung & 20 & $13(65 \%)$ & 129 \\
1988 Kaohsiung & 15 & $6(40 \%)$ & 173 \\
\hline
\end{tabular}

Source: Authors' surveys.

The Taiwanese connection businessmen to set up factories, and since 1984 125 factories have opened and another 60 are now under construction. There are currently more than 2000 permanent residents of Taiwanese nationality in South Africa. Monthly, about 200 Taiwanese businessmen fly between Johannesburg and Taipei on South African Airways (Boydell, 1988). Some of them are illicitly transporting rhino horn and hide from South Africa to Taiwan, according to Taiwanese traders. There appear to be no difficulties in smuggling rhino products into Taiwan: one main wholesaler in Kaohsiung stated that a bribe of the equivalent of US $\$ 70$ is enough to make a Customs Officer turn a blind eye. Although South Africans play an important part in the illicit trade, they do not transport horn to Taiwan themselves.

Taiwanese agricultural experts working on projects in South Africa have also been involved in the rhino horn trade. In 1986 a Taiwanese government official who happened to be resident in South Africa was caught by the authorities when he attempted to buy rhino horn through his 
wife's company for eventual export to Taiwan. Taiwanese sailors are also known to have purchased rhino horn and hide in South Africa to smuggle into Taiwan as a means of supplementing their incomes.

Not all this horn originates from rhinos that die in South Africa or Namibia. There has been serious black rhino poaching in neighbouring Mozambique recently, and some of the horn from these animals has passed through Swaziland to South Africa (J. Tello, pers. comm.). Up until late 1987, most of the horn from rhinos killed illegally in Zambia moved into Burundi from where it was exported via the United Arab Emirates to North Yemen and eastern Asia. The Burundi Government, however, stopped the trade in rhino horn and ivory in November 1987, and there is strong evidence that the horn from rhinos poached in the Zambezi valley now moves into South Africa. For example, in October 1988, a lorry carrying 94 rhino horns (loaded in Zambia) was stopped by Botswana Customs and Excise officials at the Kazungula border post, on its way down to South Africa.

Because Taiwanese businessmen are paying ever-increasing amounts for rhino horn, middlemen in some parts of Africa are now offering higher prices for their supplies. This further enhances the incentives for poaching. Taiwan has thus replaced North Yemen as the single greatest threat to the survival of the rhinoceros.

Horns from Asian rhinos are, as already noted, also in great demand in Taiwan, and this is especially endangering Sumatran rhinos, of which there may be only 800 left in all Asia. Some poachers in the state of Sabah, Malaysia, and in Indonesia have responded to the demand by increasing their efforts to kill whatever rhinos they can find (Martin, in press). Traditional Iban hunters in Sabah, armed with shotguns, may have to spend up to three months tracking one down, but the US $\$ 7300$ they are offered for the pair of horns, the nails and some of the skin from one carcass make the economic return worth the effort. None of Sabah's estimated population of 100 Sumatran rhinos is safe, and the only one kept in captivity is under guard 24 hours a day. Taiwanese traders purchase the horn from traders and medicine shop owners in Sabah 80 (mainly in the town of Tawau) and they are also buying it in Singapore and Bangkok. Most of the horn in Singapore comes from Indonesian rhinos, and that in Bangkok probably originates from rhinos in northern Thailand, Burma, Laos and Kampuchea. Thus, almost all the scattered Sumatran rhino populations are threatened by the Taiwanese.

Taiwan is one of the very few countries where there is a considerable amount of Indian rhino horn for sale, the majority of which has come from the northern state of Assam where there are 1300 greater one-horned rhinos, 75 per cent of the world's total. Until late 1986, Indian horn was mainly exported to Singapore, but since the Singapore Government banned the commerce, it appears from information supplied by traders that consignments are going to Hong Kong; some are then transhipped to Taiwan.

If prices for rhino horn continue to soar in Taiwan, the consequences for African and Asian rhinos will be disastrous. It is imperative to take immediate action against the trade in Taiwan. First, all stocks of rhino horn and hide in the country should be registered; and individual horns, of which there are hundreds, should be marked for identification. Traders and owners of the medicine shops should be given a certain time limit to sell their stocks, after which all internal sales should be made illegal. Hong Kong and Macao have already done this, in accordance with Resolution Conf. 6-10 passed at the 1987 CITES meeting in Canada, which urged all party states to implement a complete prohibition of sales, internal and external, of all rhinoceros parts and derivatives. In Taiwan, once the stocks are registered, the appropriate government officials should regularly inspect the medicine shops to check that only these are being sold to consumers, and after the ban on internal trade comes into effect, they should make sure that the medicine shops no longer sell any rhino products. Stiff fines should be imposed for noncompliance, with perhaps mandatory closure of business for those convicted of a second offence.

Even more importantly, imports of new stocks of rhino horn to Taiwan must be stopped. The Taiwanese Government does enforce its laws against certain imports, and if the decision-

Oryx Vol 23 No 2, April 1989 


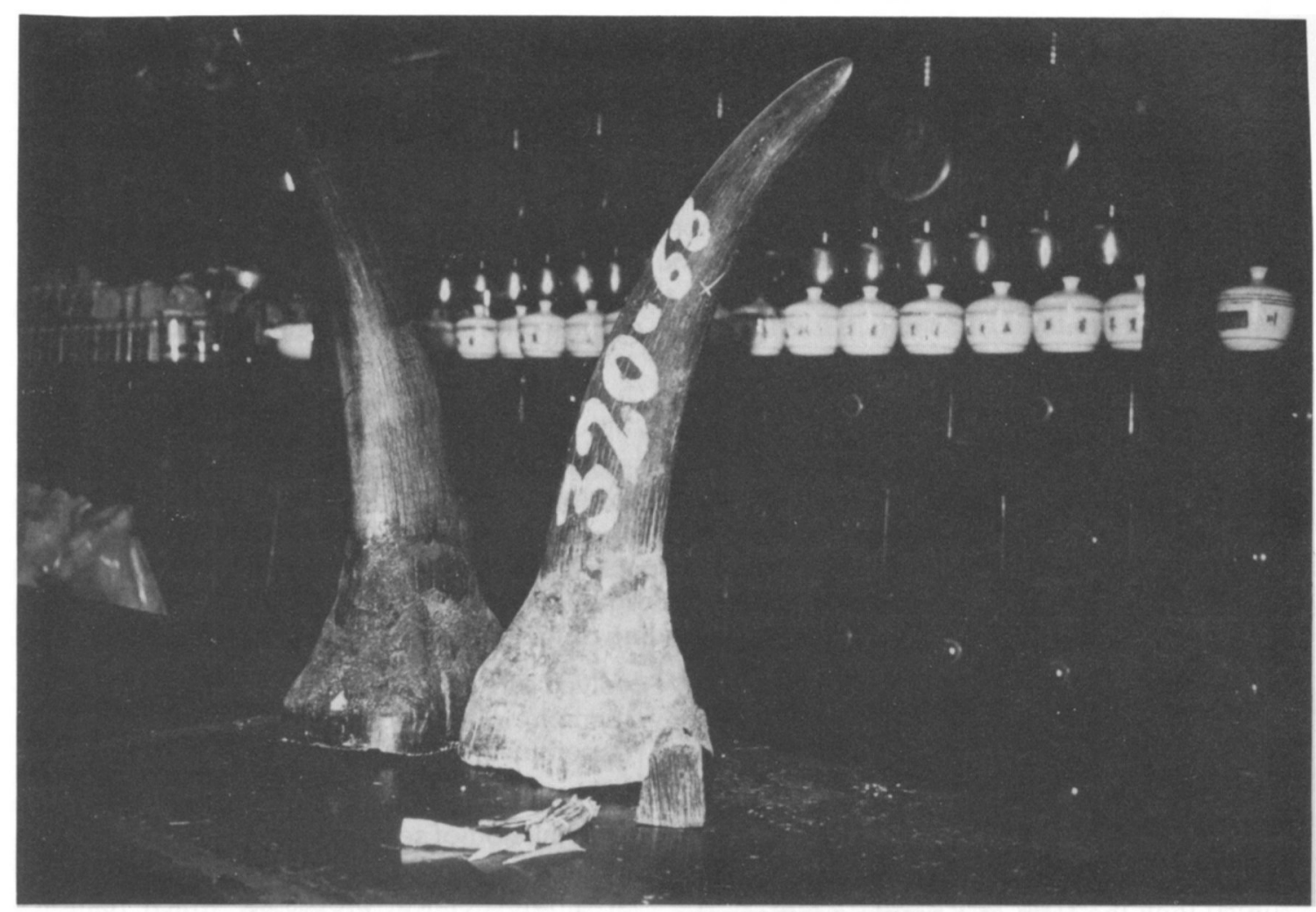

Most medicine shops in Taiwan openly display rhino horns (Esmond Bradley Martin).

makers were convinced of the importance of preventing the entry of rhino horn, action would be taken. Customs officers would be briefed on identifying horn and particulai attention would be paid to inspecting shipments coming in from South Africa. It is up to conservationists to put the necessary pressure on Taiwan.

\section{Acknowledgments}

We wish to express gratitude to the following organizations, which supported our recent visit to Taiwan (the Republic of
China): World Wide Fund for Nature, African Fund for Endangered Wildlife and Friends of Howletts and Port Lympne.

\section{References}

Martin, E. and Vigne, L. 1987. Recent developments in the rhino horn trade. Traffic Bulletin, 9, 49-53.

Boydell, M. 1988. South Africa luring Taiwan investors, Trade Winds (Taipei), No. 653, 27-28.

Martin, E.B. (in press). The illegal killing of Sumatran rhinos and the trade in their products in Western Borneo.

Esmond and Chryssee Bradley Martin, P.O. Box 15510 Mbagathi, Nairobi, Kenya. 